\title{
THE UNUSUAL BILLIONAIRES SAURABH MUKHERJEA
}

Book Reviewed by : *Dr. Vincent Raj Kumar

The Book by Saurabh Mukherjea is about seven companies which have been performing very well in India for the last 25 years; the companies are Asian Paints, Berger Paints, Marico, Page Industries, Axis Bank, HDFC and Astral Poly.

This Book reflects how these companies are thriving in the last 25 years which are predominantly ruled by Information Technology. Mukherjea evaluates the performance of these companies by using certain qualitative and quantitative parameters and the outcome of these evaluations is backed by the share value of these companies.

He mentions that enormity of these companies is not temporary, and they appear successful because of their strategies in various sectors. The author gives us the details about the company's founder, products, strategies and brand recall. Another reason for the success of these companies is their disciplined approach used for investments, which offers them maximum returns. The author further illustrates about the stocks that these companies have purchased which brought a lot of prosperity.

The book begins with an introduction story about these companies which began small and grew exponentially with time and then describes the way they were built by focusing on small opportunities or ventures which were ignored by other companies. This was the reason for the difference among these extraordinary companies who later became billionaires and others who could not move ahead as these seven companies did among competition from great companies such as Infosys, the Tata's and Reliance. These seven companies built their empire relying on their competitive advantage. The author feels that these strategies made these companies achieve better than their competitors.

The author talks about prominence and goes on to articulate that greatness is not everyone's cup of coffee. The common thread which is responsible for the success of these companies is the location of their business and the promoters who did not centralize the power and wealth of the companies to their kith and kin.

The three themes which are highlighted are:-

Theme A: Focus on long term rather than short term results.

Theme B: Using Technology to improve internal efficiencies

Theme C: Sensible Capital Allocation

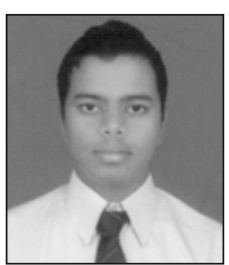

*Dr. Vincent Raj Kumar

Associate Professor

Adarsh Institute of Management and

Information Technology 
Theme A: Focus on long term rather than short term results.

These companies focus was on long term result rather than short term which are generally not the case with other companies. Other companies get attracted by short term results and get deviated from their actual vision which would be to establish competitive position and sustain them as much as possible. Short term results are something which excites every company but these companies ignored that and focused on the firms priorities.

Theme B: Using Technology to improve internal efficiencies

These companies are obsessed in using technology and cost reduction which helped them to be better than others. As they used technology in their operations they were able to improve efficiency internally which in return led to reduction in costs. When companies don't use technology it can lead to a lot of consequences such as fall in market share which can eventually lead to further loss. These companies learnt from their mistakes and established their internal environment which nurtured technology advancement with cost control. Such attitude sustains their competitive advantage.

\section{Theme C: Sensible Capital Allocation}

These companies were sensible about capital allocation i.e. they had refrained from outside core franchise and used to return excess cash to shareholders if they were unable to use the excess funds effectively. They ensured they prove before investing their capital.

The author concludes with a checklist for long term Investors which includes Industry Attractiveness, Management Quality and Competitive Advantage:- a. Industry attractiveness: The relative attractiveness which an industry has, can impact the company's fortune.

The questions which can be asked to check industry attractiveness are

i. Is the company's business heavily dependent on government regulation?

ii. How many competitors are present in the industry and how strong is the competitive intensity?

iii. What is the overall size of the industry and its growth potential?

iv. What is the capital intensity and capital efficiency of the industry?

v. Is the industry's business dependent on India's overall economic cycle?

vi. Does the business generate excess returns for shareholders?

b. Management Quality: The other important factor which evaluates the business apart from industry attractiveness is its quality of management. It is this management which will help the industry to overcome various challenges and also transform the business into an attractive sector.

The questions which can be asked to check Management Quality are:-

i. Does the management have a track record of good governance and clean accounting?

ii. Do the owners of the company have connections to political parties?

iii. Does the company have a strong track record of efficient capital allocation?

iv. Do the promoters have a track record of remaining focused on their core operations? 
c. Competitive Advantage: It is competitive advantage which allows a company to do better than the rivals, further when this competitive advantage is sustained this will allow them to continue their extra value addition for longer period.

The questions which can be asked to check Competitive Advantage are:-

i. What is the company's track record on innovation

ii. What is the company's investment in brands and reputation?

iii. How strong is the company's architecture?

iv. Does the company own any strategic assets?

The book is an illustration of unusual people becoming billionaires and the reasons for that were their determination and unique strategies, something not found very often. The seven company's history teaches us valuable lessons in personal and professional life which will enrich our lives in many facets. This doesn't mean that all who read this book will become billionaires; however there is something to learn and grow.

The book isn't an easy read; it won't make for a pleasant afternoon delight. This is a very long book and it will suit only those who are into investment and finance not lay persons.

The style of writing is narrative. The author is imparting information by constructing and communicating the stories of seven companies with characters.

This is a book worth reading, not as a result of the theoretical emphasis on business and corporate success, however as a result of it constructs which is an inexpensive framework for assessing it. It also provides a wealth of knowledge and facts on the Indian Companies who have overcome tough times and became successful.

To make the book attention-grabbing and legible, the author has provided several snapshots of the key individuals concerned with in the entire heroic tale. Clearly, this has concerned a good quantity of legwork and interviews, additionally to the gathering of secondary information.

The author shows promise, and one hopes to learn a lot from him for the future. Maybe a lot of perceptive assessment of the theoretical frameworks used by the author shall ensure big companies success. 